pain in the chest or tip of the shoulder should be examined and have chest radiography performed. If pneumothorax is confirmed the patient should be referred to a respiratory physician. Such patients tend not to have primary lung disease and so their case will be amenable to observation or simple aspiration of the pneumothorax, which can often be performed as an outpatient procedure, avoiding the trauma of chest drainage. When the pneumothoraces in our series were managed by general physicians chest drainage was used, which generally amounts to overtreatment in such cases.

Clinicians should be aware that pneumothorax is an accepted but rare complication of fine needle aspiration of lumps in the breast.

\title{
Who is your general practitioner?
}

\section{Jennifer Shaw, Josanne Holloway}

Regional Secure Unit, Prestwich Hospital, Prestwich, Salford Jennifer Shaw, MRCPSYCH, senior registrar in forensic psychiatry

Josanne Holloway, MRCPSYCH, senior registrar in forensic psychiatry

Correspondence to: Dr Shaw.

BMF 1991;303:628
Follow up of patients discharged from hospital requires closer cooperation between the hospital and community services. The general practitioner is the most appropriate person to link the various professionals concerned. On perusing the case notes of patients in this unit we noticed that many of them did not contain the name of the patient's general practitioner. We wondered whether this was an administrative error or whether the patients did not have a general practitioner. We compared a group of forensic psychiatry patients with a group of general psychiatric patients and a group of general medical patients to see how many of them were registered with a general practitioner.

\section{Patients, methods, and results}

We looked at the notes of all the inpatients in this unit, the acute psychiatric unit at Hope Hospital, and two general medical wards at Hope Hospital on 15 January 1991. There were 65 forensic psychiatry patients, 66 patients with acute psychiatric disease, and 59 general medical patients. The information that we collected from the clinical notes included the name of the general practitioner, the legal status of the patient, any psychiatric history, and the provisional diagnosis. If the general practitioner's name was not recorded on the admission sheet we asked the patients whether they had a general practitioner. If they did not

Details of patients whose case notes did not contain their general practitioner's name

\begin{tabular}{|c|c|c|c|}
\hline & $\begin{array}{c}\text { Forensic } \\
\text { psychiatry } \\
\text { patients }\end{array}$ & $\begin{array}{c}\text { Acute } \\
\text { psychiatric } \\
\text { patients }\end{array}$ & $\begin{array}{l}\text { General } \\
\text { medical } \\
\text { patients }\end{array}$ \\
\hline General practitioner not recorded & 41 & 13 & $9 \star \star \star$ \\
\hline $\begin{array}{l}\text { General practitioner unknown to } \\
\text { patient }\end{array}$ & 12 & 8 & $4^{\star}$ \\
\hline $\begin{array}{l}\text { Diagnosis: } \\
\text { Schizophrenia } \\
\text { Personality disorder }\end{array}$ & $\begin{array}{r}11 \\
1\end{array}$ & $\begin{array}{l}7 \\
1\end{array}$ & \\
\hline Detained under section of & & 2 & \\
\hline Male & $\begin{array}{l}11 \\
12\end{array}$ & $\begin{array}{l}2 \\
8\end{array}$ & 4 \\
\hline Single & 11 & 7 & 4 \\
\hline Unemployed & 11 & 8 & 4 \\
\hline No address & 4 & 1 & 3 \\
\hline Psychiatric history & 11 & 7 & 2 \\
\hline Source of admission: & & 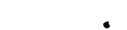 & \\
\hline Prison & 5 & 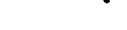 & \\
\hline Special hospital & 4 & & \\
\hline District general hospital & 2 & & \\
\hline Police station & 1 & & \\
\hline Community & & 8 & 4 \\
\hline $\begin{array}{l}\text { Patient unknown to local family } \\
\text { health services authority }\end{array}$ & 5 & & \\
\hline
\end{tabular}

We thank the surgeons concerned for allowing us to report these cases.

1 Leahy BC, Stretton TB. Pleural disease. Medicine International 1986;35: $1+46-51$

2 Thompson AM, Newman RJ, Semple JC. Brachial plexus anaesthesia for upper limb surgery: a review of eight years' experience. $尹$ Hand Surg $[\mathrm{Br}]$ 1988;13:195-8

3 Dixon JM. Immediate reporting of fine needle aspiration of breast lesions. $B M \mathcal{F}$ 1991;302:428-9.

4 Dixon JM, Anderson TJ, Lamb J, Nixon SJ, Forrest APM. Fine needle cytology in relationship to clinical examination and mammography in the diagnosis of a solid breast mass. Br F Surg 1984;71:593-6.

5 Bevelaqua FA, Aranada C. Management of spontaneous pneumothorax with small lumen catheter manual aspiration. Chest 1982;81:693-4.

(Accepted 2 fuly 1991)

know who their general practitioner was we asked the local family health services authority if they were registered. The data were analysed with a $\chi^{2}$ test.

The general practitioner's name was not documented on 59 admission sheets. Twenty patients did not know their general practitioner's name and five patients were not registered with the family health services authority at their last address. Patients who did not know the name of their general practitioner were more likely to be young, single, male, or unemployed, or to have schizophrenia, and their address was less likely to be documented in their notes. Patients in the regional secure unit were significantly less likely to have a general practitioner (table).

\section{Comment}

Our study showed that the patients' details were incompletely documented in some cases. This may be partly because some patients are disturbed and acutely ill on admission so that the details cannot be obtained. In these cases this information should be collected later. An unacceptably high proportion of patients were not registered with a general practitioner. These patients were more likely to be single, unemployed, and homeless; these are the very patients who need support and care in the community. Psychiatric patients without general practitioners are particularly at risk of relapsing because without encouragement they may not comply with treatment. Early on in an admission patients should be registered with a general practitioner, who should participate in planning follow up care.

Section 117 of the Mental Health Act 1983 states that people who are detained under sections $3,37,47$, and 48 of the act must receive follow up care on discharge, which necessitates cooperation between the hospital, community services, and general practitioner. ${ }^{1}$ Eleven of the 12 forensic psychiatric patients who did not have a general practitioner had been detained under the Mental Health Act. It is important to identify these patients early so that they can be registered with a general practitioner where they live and their follow up can be planned. The forensic psychiatry service is regionally based, and patients may be discharged to districts some distance away, so that the importance of the general practitioner in monitoring these patients and liaising with the forensic team cannot be overstated.

Patients admitted to hospital should be followed up, and this necessitates the participation of the general practitioner. Some patients will still refuse to cooperate, but if the general practitioner does participate care should be provided for most patients.

1 Blueglass RS. A guide to the Mental Health Act 1983. Edinburgh: Churchill Livingstone, 1983.

(Accepted 27 April 1991) 